\title{
Litigation before the International Court of Justice during the pandemic
}

\author{
Giulia Pinzauti and Philippa Webb* \\ Leiden University, Rapenburg 70, 2311EZ Leiden, Netherlands Email: g.pinzauti@law.leidenuniv.nl and King's College \\ London, Strand, London WC2R 2LS, UK Email: Philippa.webb@kcl.ac.uk
}

\section{Introduction}

The International Court of Justice (ICJ or Court) is a place where formality reigns and time seems to stand still. In the not-so-distant past when we used to work at the Court, in-person meetings and hard-copy documents were the lifeblood of its operations. Working closely with the judges, many a time we heard, 'If it's not on paper, it doesn't exist!' Even e-mails were printed out and delivered by hand on a regular basis. This was how the Court worked for over 70 years since its establishment.

Fast forward to March 2020, when the Covid-19 pandemic swept the world and made its way to the Netherlands, where the Court is based. In the space of a few days, the Court had to suspend its operations, initially for a month, and then until further notice. It quickly became apparent that the pandemic would not pass in a season and that the Court - like many other institutions around the world - had to adapt to a new reality.

The pandemic has radically and rapidly changed the Court's working methods and the mindsets of its judges and officials. Not long ago, many of those judges and officials would have balked at the prospect of holding virtual judicial meetings and remote or hybrid hearings. ${ }^{1}$ The pandemic has produced perhaps the greatest change to the Court's procedure in the shortest period of time. The transformation has been borne out of necessity, as the Court found a way to continue discharging its judicial functions during the emergency. Yet, the consequences of the pandemic on the administration of justice, in The Hague and elsewhere, are so pervasive that some believe that there is 'no going back to February 2020' for the courts and judiciary. ${ }^{2}$

Memories of how this extraordinary period in history affected our way of life will inevitably fade. The Smithsonian's National Museum of American History has formed a Rapid Response Collecting Task Force to preserve tangible materials (home-made face masks, test kits, the glass vial used in the first US Covid-19 vaccination) 'to document the ephemeral aspects' of this

\footnotetext{
*Assistant Professor of Public International Law at Leiden University and Professor of Public International Law at King's College London, respectively; co-editors of the ICJ Section of the Leiden Journal of International Law. The views expressed do not necessarily represent those of our past or present employers.

${ }^{1}$ In this article, 'remote hearing' refers to a hearing held with the parties participating via videoconferencing software; 'hybrid hearing' refers to a hearing where some party representatives are present in the Great Hall of Justice and some participate via videoconference. Throughout the pandemic, some judges, including the President, have been present in the Great Hall for hearings. 'virtual hearing' encompasses both remote and hybrid hearings.

${ }^{2}$ This is what Lord Burnett, the Lord Chief Justice of England and Wales, stated in evidence to the House of Lords constitution committee, regarding the work of the courts and judiciary of England and Wales. See J. Sorabji, 'Initial Reflections on the Potential Effects of the Covid-19 Pandemic on Courts and Judiciary of England and Wales', (2021) 12 International Journal for Court Administration 6.
} 
experience and 'to provide a long-term historical perspective'. ${ }^{3}$ We feel a similar need to document the experience of litigation before the ICJ during the pandemic and to reflect on what practices and working methods should be retained in the future.

In this article, we explore the impact that the pandemic has had on litigation before the ICJ from March 2020 until June 2021. Section 2 provides an overview of the challenges brought by the pandemic and briefly explains how the Court adapted its working methods in response. Section 3 focuses on virtual hearings. It analyses how the various participants in those hearings (counsel and advocates, Registry officials, state representatives, interpreters) adapted to the new situation, how they experienced the hearings, whether they raise any fairness issues, and whether physical hearings are necessary or desirable for the settlement of inter-state disputes. Finally, Section 4 draws some conclusions and recommendations.

We have drawn on secondary sources and collected data on postponements and the logistics of remote and hybrid hearings. In addition, to capture some of the challenges, surprises and perhaps benefits to inter-state litigation generated by these extraordinary times, we conducted 12 semistructured interviews with staff working at the Court and lawyers working for parties that had hearings during the relevant period. While we gathered some views from Court staff, we do not purport to represent the judges' views on any of the above issues. ${ }^{4}$

\section{The challenges brought by the pandemic at a glance}

To control the spread of the pandemic and protect public health, many states introduced sweeping measures that disrupted the functioning of society, including the work of the courts. Many states entering into lockdowns temporarily closed courts, or dramatically restricted access to them. In addition, travel restrictions affected the ability of judges, lawyers, the parties, and the public to physically access the courts even when they were open. Court hearings were postponed or held using video or audio-conferencing technology. ${ }^{5}$ The use of remote hearings accelerated. In some places, a legal basis for remote hearings was introduced with emergency legislation. ${ }^{6}$ As a result of those measures, and notwithstanding efforts to continue operations, many courts around the world are now facing massive backlogs. For example, in the United Kingdom the number of outstanding cases is now 'at record highs', with a backlog of over 530,000 cases in the criminal courts alone. ${ }^{7}$ In California there was 'a $50 \%$ reduction in the number of cases heard by the state between March to August 2020, as compared to the year prior'. ${ }^{8}$

The ICJ faced similar challenges, albeit on a smaller scale. When the Dutch Government imposed measures to prevent the spread of the coronavirus, including a ban on foreign travel and the requirement to work from home except for staff in vital professions, the Court initially decided to suspend all hearings and meetings of the Court until 16 April 2020. ${ }^{9}$ Hearings in Arbitral Award of 3 October 1899 (Guyana v. Venezuela), which were scheduled for March

\footnotetext{
${ }^{3}$ Smithsonian National Museum of American History, 'National Museum of American History Implements Collecting Strategy in Response to COVID-19 Pandemic', press release, 8 April 2020.

${ }^{4}$ The authors received ethical clearance for this project by the Research Ethics Office at King's College London (reference no. MRA-20/21-21696). The interview data was processed under the terms of the UK data protection law (including the UK General Data Protection Regulation and the Data Protection Act 2018). All participants are anonymous and identified by a number and their role (advocate/Registry official/interpreter/state representative).

${ }^{5}$ B Beyond the Emergency of the Covid-19 Pandemic: Lessons for Defence Rights in Europe', Fair Trials.org, 20 July 2020 , available at www.fairtrials.org/news/beyond-emergency-covid-19-pandemic-lessons-defence-rights-europe, at 6, 10.

${ }^{6}$ A. Sanders, 'Video-Hearings in Europe Before, During and After the COVID-19 Pandemic', (2020) 12 International Journal for Court Administration 3.

${ }^{7}$ House of Lords, Select Committee on the Constitution, 'Covid-19 and the Courts', $22^{\text {nd }}$ Report of the session 2019-21, 35.

${ }^{8}$ S. Rubley, 'Battling Court Backlogs To Ensure Access to Justice for All', New York Law Journal, 16 April 2021, available at www.law.com/newyorklawjournal/2021/04/16/battling-court-backlogs-to-ensure-access-to-justice-for-all/?slreturn=20210708152004.

${ }^{9}$ Press Release No. 2020/9, 20 March 2020.
} 
2020, were postponed until further notice. ${ }^{10}$ The suspension period was then extended until 31 May 2020. ${ }^{11}$ Likewise, the hearing on preliminary objections in Application of the International Convention on the Elimination of All Forms of Racial Discrimination (Qatar v. United Arab Emirates) was postponed by a few months in consultation with the parties. ${ }^{12}$ Other postponements were requested by the parties by invoking delays and challenges associated with the pandemic. Kenya requested the postponement of the merits hearing in Maritime Delimitation in the Indian Ocean (Somalia v. Kenya), which was scheduled to take place in June 2020. ${ }^{13}$ Other states requested extensions of the time limits for filing their written pleadings. In Application of the Convention on the Prevention and Punishment of the Crime of Genocide (The Gambia v. Myanmar), The Gambia requested and obtained a three-month extension for the filing of the initial pleadings. ${ }^{14}$ In Guatemala's Territorial, Insular and Maritime Claim (Guatemala/Belize), the Court granted Guatemala an additional six months (instead of the requested 12 months) to file its Memorial, and gave Belize a one-year extension. ${ }^{15}$ Finally, in Application of the International Convention for the Suppression of the Financing of Terrorism and of the International Convention on the Elimination of All Forms of Racial Discrimination (Ukraine v. Russian Federation) the Court initially granted a four-month extension to the Russian Federation for the filing of its Memorial. ${ }^{16}$ Following a second request for an extension submitted by the Russian Federation, the Court granted an additional three months. ${ }^{17}$ In the face of a third request for an extension, the Russian Federation was permitted to further extend the time limit for filing its Memorial by one month. ${ }^{18}$

Meanwhile, the Court adapted its working methods to the new reality. To ensure business continuity, the Court provided judges and staff with the necessary hardware and software to work remotely. ${ }^{19}$ According to a press release issued by the Court, ' $[t]$ hrough the use of modern technologies, the Court has made the necessary arrangements to hold virtual meetings and adapted its working methods to the need to work remotely during the COVID-19 pandemic'. ${ }^{20}$ On 23 April 2020, the Court held the first remote plenary meeting in its history. ${ }^{21}$ New arrangements were made for the electronic filing of certain documents (such as reports on the implementation of provisional measures and judges' folders for oral pleadings), but written pleadings and the signed original reports on provisional measures were still filed in hard copy. ${ }^{22}$

\footnotetext{
${ }^{10}$ Press Release No. 2020/8, 17 March 2020.

${ }^{11}$ Press Release No. 2020/10, 7 April 2020.

${ }^{12}$ Interview with advocate 8, 4 June 2021 ('interview with advocate 8').

${ }^{13}$ Press Release No. 2020/13, 22 May 2020.

${ }^{14}$ The respondent disagreed but ultimately took no position on the request. Application of the Convention on the Prevention and Punishment of the Crime of Genocide (The Gambia v. Myanmar), Order of 18 May 2020, [2020] ICJ Rep. 75.

${ }^{15}$ Guatemala's Territorial, Insular and Maritime Claim (Guatemala/Belize), Order of 22 April 2020, [2020] ICJ Rep. 72. In this case, Belize objected to the request and argued that if the pandemic was a sufficient reason to grant an extension, a twomonth extension would be sufficient (ibid., at 73).

${ }^{16}$ The Russian Federation had requested an additional 12 months, on the ground that the Covid restrictions had caused delays in the preparation of the pleading; Ukraine opposed the request. Application of the International Convention for the Suppression of the Financing of Terrorism and of the International Convention on the Elimination of all Forms of Racial Discrimination (Ukraine v. Russian Federation), Order of 13 July 2020, [2020] ICJ Rep. 78.

${ }^{17}$ Application of the International Convention for the Suppression of the Financing of Terrorism and of the International Convention on the Elimination of all Forms of Racial Discrimination (Ukraine v. Russian Federation), Order of 20 January 2021. This request was also opposed by Ukraine.

${ }^{18}$ Application of the International Convention for the Suppression of the Financing of Terrorism and of the International Convention on the Elimination of all Forms of Racial Discrimination (Ukraine v. Russian Federation), Order of 28 June 2021 (with the Court expressly noting that 'two key individuals involved in the preparation of that pleading had been diagnosed with COVID-19 and were temporarily prevented from working because of the severe effects of the virus').

${ }^{19}$ Interview with Registry official, 26 May 2021 ('interview with Registry official').

${ }^{20}$ Press Release No. 2020/11 23 April 2020.

${ }^{21}$ Ibid. Prior to that, meetings of the Court's committees had taken place by videoconference.

${ }^{22}$ Interview with Registry official.
} 
On 25 June 2020, the Court amended Articles 59 and 94 of the Rules of Court to permit the holding of hearings and the reading of judgments, respectively, 'by video link' in whole or in part, if health, security or other compelling reasons so demand. ${ }^{23}$ Article 59(2) of the Rules further provides that the parties shall be consulted on the organization of the hearing. On 30 June 2020, the Court held its first remote hearing in Guyana v. Venezuela, followed by four other virtual hearings between August 2020 and June 2021. ${ }^{24}$

Hearings and judicial meetings by videoconference represent a fundamental change in the Court's practice and culture. A first obvious challenge was getting the infrastructure up and running, and ensuring that every participant was able to master the technology. The Court issued detailed technical instructions to the parties on how to access the hearing platform, use it, and share content (such as slide presentations), and on how to use the separate interpretation platform if needed. The Court's instructions also set out appropriate standards regarding internet connection and the minimum network bandwidth speed, as well as the use of headsets with built-in microphones to facilitate simultaneous interpretation. Detailed and multiple test sessions were held with the parties prior to each hearing. To protect the confidentiality, integrity, and availability of information, the Court took some basic measures to restrict access to documents and meetings to authorized individuals only, while the Court's Information Technology department closely monitors the Court's activities. ${ }^{25}$ Other challenges for the Court included the impact on the principle of equality of arms. We take a closer look at how these issues played out in practice in the next section.

\section{Virtual hearings: Challenges and prospects}

\subsection{Why focus on oral pleadings?}

We focus on the impact of the pandemic on oral pleadings at the ICJ for two reasons. First, and put simply, because they matter. Oral pleadings give the parties an opportunity to put their case before the Court in the clearest possible way. Because time is limited, advocates have to identify and distil the most important issues. ${ }^{26}$ According to one regular advocate before the Court, 'Oral advocacy, even if it is a formal affair, really makes people think further ... [and] choose the three good points to focus on'. ${ }^{27}$ This exercise helps the Court 'navigate through an overwhelming mass of paper' ${ }^{28}$ The parties also have the opportunity to respond to each other's arguments in a more direct way as compared to the written pleadings. ${ }^{29}$ In so doing, they can adjust their arguments to find areas of common ground, distil the points of contention, and reflect recent developments. ${ }^{30}$ The judges, for their part, are focused on listening to the parties' arguments, and have an opportunity to engage directly with them through questions. ${ }^{31}$ There is some evidence that judges have changed their mind regarding the outcome of a case after the close of the oral phase. ${ }^{32}$ Last but not

\footnotetext{
${ }^{23}$ Press Release No. 2020/16, 25 June 2020.

${ }^{24}$ Application of the International Convention on the Elimination of All Forms of Racial Discrimination (Qatar v. United Arab Emirates), Preliminary Objections (31 August-7 September 2020; Alleged Violations of the 1955 Treaty of Amity, Economic Relations, and Consular Rights (Islamic Republic of Iran v. United States of America), Preliminary Objections (14-21 September 2020); Maritime Delimitation in the Indian Ocean (Somalia v. Kenya) (15-18 March 2021); Armed Activities on the Territory of the Congo (Democratic Republic of the Congo v. Uganda) (20-30 April 2021).

${ }^{25}$ Interview with Registry official.

${ }^{26}$ S. Wordsworth and K. Parlett, 'Advocacy', in (2019) Max Planck Encyclopedia of International Procedural Law, para. 19.

${ }^{27}$ Interview with advocate 5, 27 May 2021 ('interview with advocate 5').

${ }^{28}$ See Wordsworth and Parlett, supra note 26, at para. 19.

${ }^{29}$ Interview with advocate 6, 1 June 2021 ('interview with advocate 6').

${ }^{30}$ Interview with advocate 8 .

${ }^{31}$ Interview with state representative, 18 June 2021 ('interview with state representative').

${ }^{32}$ Judge Sir Christopher Greenwood, in an interview for the University of Cambridge Alumni Arbitration Law Association, 18 January 2020, available at essexcourt.com/sir-christopher-greenwood-qc-interviewed-as-part-of-camarb-series/ (at 1:01:08).
} 
least, hearings traditionally provide the opportunity for representatives of the parties to the dispute to meet in a neutral setting, the Peace Palace. As we explore in more detail below, the ritual and symbolism of adjudication can help ease the tension between the parties and facilitate the resolution of the dispute. ${ }^{33}$

Second, oral pleadings are the phase of ICJ proceedings that has undergone the most dramatic adjustments due to the pandemic. The switch to virtual hearings was undoubtedly a significant change in the Court's practice.

We asked our interviewees to comment on six main issues related to oral pleadings: the preparation and organization of pleadings, their overall experience, whether virtual hearings raise any fairness issues, any added value of in-person hearings, and whether the Court should retain the practice of remote and hybrid meetings and hearings in the future.

\subsection{Preparing for the hearing}

\subsubsection{Remote meetings}

During the pandemic, preparatory meetings within the teams, with the Court and with the state client largely had to take place remotely. This made it easier to schedule the meetings, and increased their efficiency in a number of respects (for example, by reducing travel and the length of the meetings). ${ }^{34}$ Another benefit of remote team meetings is that they can be more inclusive, with more people being able to join, including a greater number of state representatives and junior counsel. ${ }^{35}$ However, some interviewees pointed out that the human interaction that is typical of in-person gatherings is lost to some extent in online meetings. ${ }^{36}$ While the efficiency gains outweigh the negatives for meetings concerning administrative matters, some observed that in-person meetings remain important when strategic decisions need to be made, or when meeting with the client for the first time. ${ }^{37}$ Moreover, difficult discussions are best handled in person rather than remotely. ${ }^{38}$ Those considerations aside, it seems that everyone has become used to remote meetings over time. ${ }^{39}$ According to one state representative, it was important to put effort into choosing counsel who would be good team players and then to 'build up a strong model of working together online so that when we got to the stage of the hearing, we were able to cooperate effectively as a team' - albeit from different locations. ${ }^{40}$ Overall, it is hard to imagine that the practice of online meetings will not be retained in some form in the future. ${ }^{41}$

\subsubsection{Advocacy via videoconference}

There are differences in how counsel and advocates prepared for remote oral pleadings as compared to in-person hearings. In terms of substance, preparation was somewhat similar because advocates before the Court typically read a script and there are no spontaneous questions from the Bench. ${ }^{42}$ Delivering the speech into a camera rather than at the lectern in the Great Hall of Justice did require a new set of calculations for gaining and keeping the Court's attention, including shortening speeches, choosing a neutral background, and ensuring a quiet environment. ${ }^{43}$ One

\footnotetext{
${ }^{33}$ Interview with advocate 1, 24 May 2021 ('interview with advocate 1'); interview with state representative. This is subject to the parties involved and the subject-matter of the dispute.

${ }^{34}$ Interview with advocate 1; interview with advocate 2, 26 May 2021 ('interview with advocate 2'); interview with advocate 5.

${ }^{35}$ Interview with advocate 3, 27 May 2021 ('interview with advocate 3'); interview with advocate 8.

${ }^{36}$ Interview with advocate 1 .

${ }^{37}$ Interviews with advocates $2,3$.

${ }^{38}$ Interview with advocate 3 .

${ }^{39}$ Interview with advocate 5; interview with advocate 7, 1 June 2021 ('interview with advocate 7').

${ }^{40}$ Interview with state representative.

${ }^{41}$ Interviews with advocates 7,8 .

${ }^{42}$ Interview with advocate 4, 27 May 2021 ('interview with advocate 4'); interview with advocate 5.

${ }^{43}$ Interviews with advocates 1, 2, 6 .
} 
advocate spent a long time thinking 'about the pros and cons of reading [his script] off the computer screen or on paper' and whether to stand or sit for delivery of the pleading. ${ }^{44}$ The logistics of using visual aids was also more complicated; for example, the assistant operating the slides may be in another country, in a different time-zone. ${ }^{45}$ Some advocates ended up using fewer visual aids, or a skeleton argument rather than slides. ${ }^{46}$

\subsubsection{Filing documents}

For advocates and representatives of the parties, the electronic filing of certain documents, which was introduced during the pandemic, is one of the biggest upsides of these extraordinary times. They were 'relieved' not to have to file dozens of hard copies. ${ }^{47}$ The logistics of arranging judges' folders was much easier; ${ }^{48}$ overall electronic filing was seen as a 'huge improvement'. ${ }^{49}$

\subsubsection{Cybersecurity}

The fact that judges, their assistants, and lawyers may work on case materials remotely exacerbates the risk of data interception..$^{50}$ Confidential documents shared by electronic means rather than printed copies or USB keys require encryption measures. ${ }^{51}$ None of our interviewees reported taking additional cyber security measures to protect the confidentiality, integrity, and availability of information concerning ICJ cases when working remotely. However, it appears that some clients are selective regarding platforms used for remote meetings. ${ }^{52}$

\subsection{Organization of the hearing}

\subsubsection{Scheduling}

With participants in remote hearings scattered across different time-zones, the Court has been sitting for only one session per day (usually $3 \mathrm{pm}-6 \mathrm{pm}$ ) rather than two. Remote hearings are also more tiring than in-person hearings and more breaks are needed. ${ }^{53}$ Consequently, the oral phase takes longer. Overall, scheduling appeared to be easier for counsel, ${ }^{54}$ and a bit more complicated for Registry officials. ${ }^{55}$

\subsubsection{Courtroom set-up and interaction with judges}

In the first remote hearing in Guyana v. Venezuela in June 2020, the Court opted for a model whereby the President and some judges, as well as Registry officials, were physically present in the Great Hall of Justice, taking the necessary Covid precautions of being masked or wearing face shields and maintaining social distance, and counsel and advocates participated remotely via video conference. The following two hearings adopted this model, ${ }^{56}$ but in Somalia v. Kenya and DRC v.

\footnotetext{
${ }^{44}$ Interviews with advocates $1,6$.

${ }^{45}$ Interview with advocate 3 .

${ }^{46}$ Interviews with advocates 5,8 .

${ }^{47}$ Interview with state representative.

${ }^{48}$ Interview with advocate 7.

${ }^{49}$ Interview with advocate 9, 11 June 2021 ('interview with advocate 9').

${ }^{50}$ ILA Committee on Procedure of International Courts and Tribunals, Final Report, 1 May 2020 (ILA Final Report), 32.

${ }^{51}$ Ibid., at 35

${ }^{52}$ Interviews with advocates 3,5 .

${ }^{53}$ R. Susskind, 'The Future of Courts', (2020) 6 The Practice, available at thepractice.law.harvard.edu/article/the-future-of-courts/.

${ }^{54}$ Interview with advocate 1 .

${ }^{55}$ Interview with Registry official.

${ }^{56}$ Application of the International Convention on the Elimination of All Forms of Racial Discrimination (Qatar v. United Arab Emirates), Preliminary objections (31 August-7 September 2020; Alleged Violations of the 1955 Treaty of Amity, Economic Relations, and Consular Rights (Islamic Republic of Iran v. United States of America), Preliminary Objections (14-21 September 2020).
} 
Uganda, a hybrid model was followed whereby some representatives of the parties attended the hearings in person while others participated remotely.

Undoubtedly, hearings by videoconference are not as majestic as hearings in which the full Court convenes in the Great Hall of Justice. One advocate observed, 'There is a certain presence and energy in the Great Hall ... there is a reason why you have physical structures - the Peace Palace with its ornate architecture is a lieu de memoire ... a building that stands for something greater than yourself. ${ }^{57}$ One of the disadvantages of virtual hearings is that they look more like a business meeting or conference than a solemn judicial hearing. However, having the presence of the President and several judges in the Great Hall helped maintain some of 'the symbolism of adjudication'. ${ }^{58}$ As one advocate put it, 'when judges move into the Great Hall, suddenly they are human beings' ${ }^{59}$ While there is, of course, no obligation for judges to accept a higher degree of risk than others by, for example, expecting them to sit in person while everyone else in the community is working remotely, ${ }^{60}$ they deserve part of the credit for the solemn and meaningful conduct of hearings during this period. Their physical presence is not, in fact, required for the quorum to constitute the Court under Article 25(3) of the Statute. As the President made clear during the first remote hearing in Guyana v. Venezuela, both judges physically present in the courtroom and those participating remotely form the Court's composition in a given case. ${ }^{61}$ The Netherlands has recognized the fundamental role performed by the Court, alongside other international institutions, for the promotion of the international legal order, and permitted persons performing necessary work for the Court to benefit from certain exemptions from the Covid restrictions. ${ }^{62}$ This has facilitated access to the Court for judges and lawyers, and made hybrid hearings possible.

One of the biggest challenges for advocates pleading remotely is that it is practically impossible for them to establish eye contact with the judges and read their reactions. ${ }^{63}$ Advocates lamented that they do not even have a clear view of the Bench on the screen, with the exception of the President. ${ }^{64}$ They have a better view of the judges that are participating remotely, who appear in individual windows on the screen. ${ }^{65}$ Conversely, advocates who have appeared in person in hybrid hearings have little to no interaction at all with those judges participating remotely. ${ }^{66}$ As a result of these technological barriers, all interviewees agreed that there is 'hardly any' interaction with the judges: 'Nuances are lost. It is more difficult to solicit a reaction, the "aha" moment ... your relationship is with the camera. ${ }^{67}$ One advocate defined the experience of pleading remotely as a 'one-man show' and went so far as to suggest that they could have submitted the text of the pleading to the Court without going through the act of reading it into a camera. ${ }^{68}$ When we put this proposition to the other interviewees, they disagreed with it. The prevailing view is that 'oral hearings make a difference, even at the ICJ', even if they take place via video conference. ${ }^{69}$

\footnotetext{
${ }^{57}$ Interview with advocate 1.

${ }^{58}$ Interview with advocate 6 .

${ }^{59}$ Interview with advocate 7.

${ }^{60}$ International Commission of Jurists, 'The Courts and COVID-19', 5 May 2020, available at www.icj.org/wp-content/ uploads/2020/05/Universal-ICJ-courts-covid-Advocacy-Analysis-brief-2020-ENG.pdf, at 6.

${ }^{61}$ CR 2020/5, at 9.

${ }^{62} \mathrm{Cf}$. www.government.nl/topics/coronavirus-covid-19/visiting-the-netherlands-from-abroad/self-quarantine/exemptions.

${ }^{63}$ Interviews with advocates $1,3,6$; interview with state representative.

${ }^{64}$ Interviews with advocates $1,3,4$; interview with state representative.

${ }^{65}$ Interview with advocate 4.

${ }^{66}$ Interview with advocate 7.

${ }^{67}$ Interviews with advocates $1,2,5,8$.

${ }^{68}$ Interview with advocate 2 .

${ }^{69}$ See Section 3.1 supra.
} 


\subsubsection{Communication with other counsel and team members}

One of the practical challenges with pleading remotely is communicating with other counsel and team members. The technology employed by the Court does not allow for free and confidential exchanges between counsel during hearings. Most advocates we interviewed communicated using WhatsApp or e-mails, ${ }^{70}$ or reported that exchanges were 'nearly absent ${ }^{\text {'1 }}$ or 'difficult'. ${ }^{72}$ Given the scripted nature of ICJ pleadings, there tends to be little or no need for counsel to communicate instantaneously, ${ }^{73}$ but it is easier to be in the same room with the client and other team members if certain adjustments to timing need to be made at the last minute ${ }^{74}$ or when preparing for the second round of oral arguments. ${ }^{75}$

\subsubsection{Witness examination}

The conventional wisdom is that witness examination is best conducted in person. Some scholars argue that it is necessary to be in the same room as the witness to observe non-verbal communication, which is less apparent on video, and determine if they are speaking the truth. ${ }^{76}$ What emerged from our interviews is a different picture. For context, experts gave evidence in the remote hearing in DRC v. Uganda. Our interviewees indicated that examination and crossexamination work very well remotely. ${ }^{77}$ When both the advocate and the witness appeared remotely, the view was very clear: 'it was almost one-to-one rather than many metres away in the courtroom. In some ways, it was better physical communication than in person'. ${ }^{78}$ When the advocate was in the Great Hall and the witness was on screen, the situation was more challenging because the position of the relevant screen slightly to the side of the courtroom did not provide a direct view of the witness. ${ }^{79}$

Examining witnesses remotely raises other practical challenges. For example, it is not clear how one party could object to a question asked of a witness if the platform used by the Court only allows one party to connect at a time (namely, the party examining the witness). A protocol or Practice Direction setting out clear rules for remote witness examination would be highly desirable. ${ }^{80}$

\subsubsection{Interpretation}

The Court conducts hearings in both English and French with simultaneous interpretation. Virtual hearings pose challenges to smooth interpretation for a variety of reasons. The interpreters' job becomes more difficult when the quality of sound is compromised because, for example, the speaker does not use a headset with a built-in microphone. Without counsel being physically present, interpreters cannot observe their body language (for example, if they flip pages and skip some sections of their speech). Interpreters can see the speaker's lips on screen, but a slight delay in transmission makes lip reading difficult. Moreover, the pandemic has changed the nature of the interpreters' work from a collaborative endeavour to an isolated one because they can no longer share a booth with their team member for safety reasons: 'the feeling is a

\footnotetext{
${ }^{70}$ Interviews with advocates $1,3,6$; interview with state representative.

${ }^{71}$ Interview with advocate 8 .

${ }^{72}$ Interview with advocate 2. Contra: Interview with advocate 4 (arguing that the most significant advantage of remote hearings is that it is easier to communicate with other team members, even if via telephone or e-mail).

${ }^{73}$ Interview with advocate 1 .

${ }^{74}$ Interview with advocate 3 .

${ }^{75}$ Interview with advocate 6 .

${ }^{76}$ See Susskind, supra note 53.

${ }^{77}$ Interview with advocate 5.

${ }^{78}$ Interview with advocate 4 . Yet, if the witness was present in court, they would choose to be present in court as well.

${ }^{79}$ Interview with advocate 7.

${ }^{80}$ Interview with advocate 3 .
} 
bit eerie because you are completely detached' ${ }^{81}$ Without quality interpretation, the proceedings can become more cumbersome; more importantly, the parties may not be able to present their arguments clearly and effectively.

As already mentioned, the Court uses a separate platform for simultaneous interpretation, which means that those wishing to listen to the interpreters have to switch between two different platforms using different devices. This has proven a challenge. ${ }^{82}$ While the Court is working on a technical solution that is effective and user-friendly, it is suggested some technical problems could be avoided if the speakers used proper microphones, a cabled internet connection, and transmitted the text of their speech to the interpreters well in advance. ${ }^{83}$

\subsubsection{Costs}

From the state client's perspective, remote hearings could have a significant positive impact on travel and accommodation costs as well as the administrative burden that comes with litigation. ${ }^{84}$ These gains may be counterbalanced by the extra time spent by counsel preparing for the hearing, including technical tests. ${ }^{85}$ From the Court's perspective, the initial investment in building the necessary infrastructure and hiring extra equipment (e.g., for the interpreters' booths) was significant, and there were no major savings gained from holding virtual hearings. ${ }^{86}$

\subsection{Overall experience in comparison with in-person hearings}

From our interviews, it is apparent that advocates, interpreters, Registry officials, and state representatives have a strong preference for in-person hearings. ${ }^{87}$ Remote or hybrid hearings are a 'second best' alternative. ${ }^{88}$ Some conceded this view is a question of personal preference rather than effectiveness: 'I miss the solemnity and significance [of pleading in person], the fun of working with team members, the adrenalin. But those things are for me. ${ }^{89}$ Those advocates who experienced both remote and hybrid formats favoured the latter. ${ }^{90}$

For the Registry, there was relief at being able to 'have a hearing at all' ${ }^{\text {'1 }}$ during the pandemic. Interestingly, some parties would have rather faced a delay and have an in-person hearing rather than have a timelier remote hearing. ${ }^{92}$

Once the remote and hybrid hearings were arranged, 'everything worked perfectly well'. ${ }^{93}$ The technical problems that advocates experienced were defined as 'minor"94 and they even had the effect of creating 'a sense of solidarity' with the other party. ${ }^{95}$ The President handled any technical issues swiftly and the hearing was usually only suspended for a few minutes.

\footnotetext{
${ }^{81}$ Interview with interpreter, 1 June 2021 ('interview with interpreter'). See also supra note 5, at 30.

${ }^{82}$ Interview with Registry official.

${ }^{83}$ Interview with interpreter.

${ }^{84}$ Interview with state representative.

${ }^{85}$ Interview with advocate 3 .

${ }^{86}$ Interview with Registry official.

${ }^{87}$ E.g., interviews with advocates 3, 5, 6, 7; interview with state representative; interview with Registry official; interview with interpreter.

${ }^{88}$ Interview with advocate 5 .

${ }^{89}$ Interview with advocate 6.

${ }^{90}$ Interviews with advocates 3, 4 .

${ }^{91}$ Interview with Registry official.

${ }^{92}$ Interview with advocate 5 ; interview with state representative.

${ }^{93}$ Interview with advocate 5 .

${ }^{94}$ Interview with Registry official; interview with advocate 4; interview with state representative.

${ }^{95}$ Interview with advocate 8 .
} 
Yet, some advocates - and especially those participating remotely from their home - found the whole experience 'disappointing', 96 'stressful' ${ }^{97}$ or 'boring. ${ }^{98}$ Some reported that they found it 'more difficult to focus' compared to in-person hearings. ${ }^{99}$

\subsection{Considerations of fairness}

Ensuring the fairness of the proceedings and the equality of arms takes on new significance in a virtual setting. Several interviewees expressed the concern that remote or hybrid hearings may create inequalities as a result of disparity in the availability of the necessary technology and resources amongst parties, or if only one party appears in person in the Great Hall. ${ }^{100}$ States without a stable internet connection may have a preference for in-person hearings. ${ }^{101}$ To safeguard the fairness of the proceedings, the Court allows the parties to appear in person only when both parties agree and can participate. If a stable internet connection or other technical issues are a concern, parties have the possibility to come to The Hague and make their arguments from their embassy premises. ${ }^{102}$ According to one advocate, a more flexible approach in this regard would have been preferable, leaving the choice of the mode of participation to the parties. ${ }^{103}$ However, the prevailing view is that fairness requires both parties to be present, and to be represented by delegations that are equal in size, or for both parties to be participating remotely. ${ }^{104}$ This is clearly an area where there are some sensitivities for the parties: if only one party has representatives in the Great Hall 'this may give the unwarranted impression that they may be more respectful of the Court' than the other party participating remotely. ${ }^{105}$ Another advocate worried 'the Court may think less of those who do not appear in person'. ${ }^{106}$ It is very important for parties to receive clear and timely information from the Registry on the composition of each party's delegation and how many, if any, will be in the Great Hall. In the case of hybrid hearings, the parties also need clear information on the applicable sanitary regulations upon arrival in the Netherlands, including on whether and under which conditions they may be relaxed for ICJ participants. ${ }^{107}$

A recurring concern was about the presence of judges ad hoc. Even though judges ad hoc take part in the Court's decision 'on terms of complete equality with their colleagues', ${ }^{108}$ several interviewees expressed the view that it would be important for both judges ad hoc to be present or for both to participate remotely in order to avoid the perception that one party might be at a disadvantage. ${ }^{109}$

This issue was squarely before a specially constituted chamber at the International Tribunal for the Law of the Sea (ITLOS) in Dispute concerning Delimitation of the Maritime Boundary between Mauritius and Maldives in the Indian Ocean (Mauritius/Maldives). In October 2020, the Special Chamber held a hybrid hearing on the preliminary objections raised by the Maldives. The judge ad hoc appointed by Mauritius, Professor Schrijver, was physically present, whereas the judge ad hoc

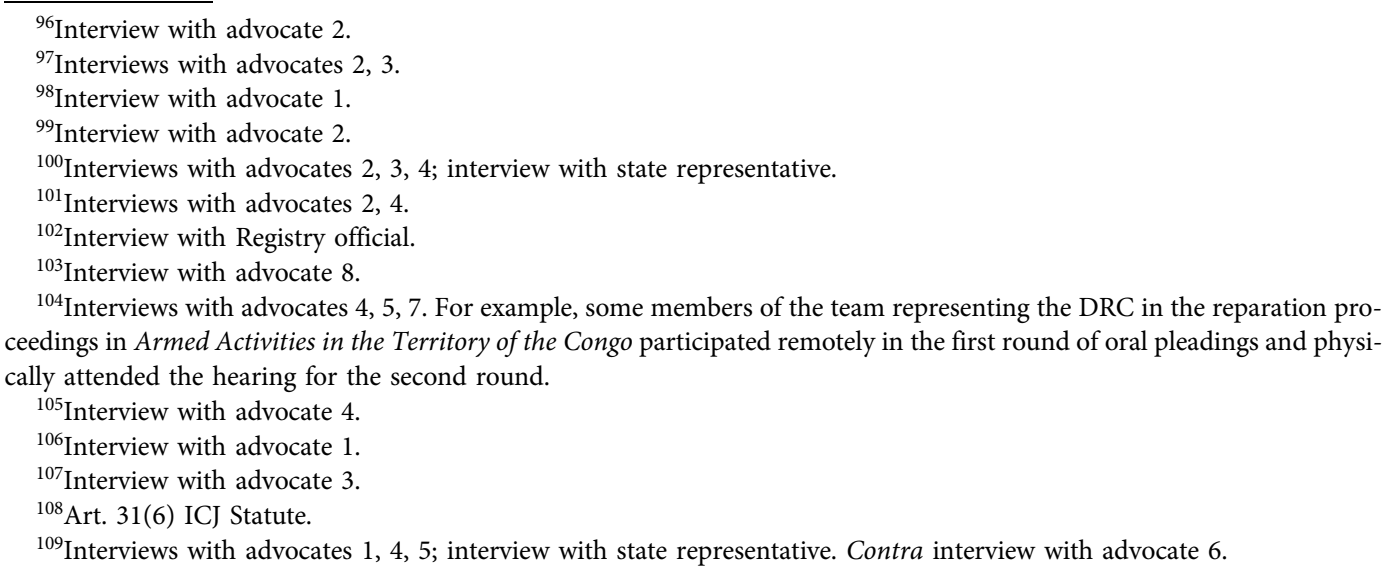


appointed by the Maldives, Professor Oxman, participated remotely. The Maldives raised concerns about the participation of the judges ad hoc in the proceedings 'by different means' and requested that Judge ad hoc Schrijver be asked to participate remotely. ${ }^{110}$ In dismissing those requests, the President of the Special Chamber stated that there is no difference between participating in the proceedings in person or remotely, and that each member of the Special Chamber would be given the opportunity to fully participate, irrespective of the mode of participation. Moreover, he said, judges ad hoc participate in a case in terms of 'complete equality' with the other judges. Given that each member of the Special Chamber could decide whether to participate in person or via videoconference, he concluded that there were no grounds to treat judges ad hoc differently. ${ }^{111}$

At the ICJ, there have been two cases to date in which the judge ad hoc appointed by one party participated remotely in the hearing and deliberations whereas the judge having the nationality of the other party was physically present. ${ }^{12}$ No challenges were raised by any party. Arguably, if the issue were raised in the future, one can foresee that the ICJ would handle it in the same way as the ITLOS Special Chamber. In our view, fairness may require the judges ad hoc to participate in the same way (remote or in-person). Their classic statement by Judge ad hoc Elihu Lauterpacht on the role of the judge ad hoc emphasizes 'the special obligation to endeavour to ensure that, so far as is reasonable, every relevant argument in favour of the party that has appointed [the judge ad hoc] has been fully appreciated in the course of collegial consideration'. ${ }^{113}$ It is almost inevitable that that special obligation is more effectively discharged in person, over coffee, around the judges' table, in the robing room, than over Webex.

\subsection{Are in-person hearings necessary for the parties to ICJ cases to fully present their case?}

We asked our interviewees whether they thought that in-person hearings are necessary for the parties to fully present their case. From the Registry's perspective, it makes little difference whether an advocate delivers their speech in person or into a camera. ${ }^{114}$ Interestingly, advocates' views on this question are divided. Some answered in the affirmative, ${ }^{115}$ while others expressed the view that physical presence matters less for the ICJ than for other tribunals given the scripted nature of proceedings, and that remote hearings serve their purpose effectively. ${ }^{116}$ In their view, states are not prejudiced by virtual hearings. ${ }^{117}$ One advocate argued that while physical hearings are not strictly speaking 'necessary' for the parties to fully present their case, they are nonetheless 'important'. ${ }^{118}$

We tried to unravel the importance of in-person hearings for the settlement of inter-state disputes at the ICJ. There are three principal strands of argument. First, the 'symbolism of adjudication', ${ }^{119}$ the 'solemnity' or 'ceremonial element' of appearing before a Bench are perceived to be significant factors in inter-state dispute settlement. ${ }^{120}$ These elements are clearly stronger in the

\footnotetext{
${ }^{110}$ Dispute concerning Delimitation of the Maritime Boundary between Mauritius and Maldives in the Indian Ocean (Mauritius/Maldives), Preliminary Objections, Judgment of 28 January 2021, para. 29.

${ }^{111}$ Ibid., para. 34.

${ }^{112}$ Maritime Delimitation in the Indian Ocean (Somalia v. Kenya) and Armed Activities on the Territory of the Congo (Democratic Republic of the Congo v. Uganda).

${ }^{113}$ Application of the Convention on the Prevention and Punishment of the Crime of Genocide (Bosnia and Herzegovina $v$. Yugoslavia), Provisional Measures, Order of 13 September 1993, [1993] ICJ Rep. 325, at 409, para. 6 (Judge ad hoc Lauterpacht).

${ }^{114}$ Interview with Registry official.

${ }^{115}$ Interviews with advocates $2,3,5,8$.

${ }^{116}$ Interviews with advocates 4,6 ; interview with state representative.

${ }^{117}$ Interview with advocate 7.

${ }^{118}$ Interview with advocate 1.

${ }^{119}$ Interview with advocate 6.

${ }^{120}$ Interviews with advocates 1,2 .
} 
presence of the Court. Second, the diplomatic dimension of inter-state dispute settlement also benefits from physical presence. In-person hearings provide an opportunity for the parties to meet and use backchannels to solve problems: the Peace Palace is a neutral venue where we can meet in the corridor [and] avoid misunderstandings'. ${ }^{121}$ Opposing counsel typically know each other and are friendly towards one another. The simple fact of attending a hearing and experiencing the culture of the Peace Palace may be an important lesson for state representatives in terms of de-escalating tensions between the parties: the agents 'realise that we are advocates who are able to behave professionally' and not make the dispute personal. ${ }^{122}$ Virtual hearings are not nearly as effective in this respect. Third, 'oral advocacy is in the courtroom'. ${ }^{123}$ Advocacy is about persuasion and physical presence in the courtroom helps everyone (the parties, counsel, judges) concentrate on the important points. ${ }^{124}$

\section{Assessment and recommendations}

As Susskind has put it, it is possible to regard the past few months as 'a huge unscheduled pilot, a great experiment in the use of a variety of technologies' ${ }^{\prime 25}$ within the courts. This observation applies also to the ICJ. More than year on from the first lockdown is a good time to take stock of this experience and reflect on the lessons learned and the way forward. This is an area where more systematic research is needed to assess what has been achieved, and what needs improving. We offer some preliminary reflections based on our research in the hope of starting the conversation.

In our assessment the Court adapted well to the conditions created by the pandemic. The conventional wisdom is that the Court is a traditional and conservative institution where any change happens at a glacial place. Yet, recent events suggest otherwise. In the space of a few weeks, the Court made a tremendous leap forward in the digitization of its services to continue operating during the pandemic. The same judges that were used to in-person meetings and stacks of paper documents managed the change swiftly and effectively, with the Registry's support. By making use of technology, and by making adjustments at the instigation of some of the parties, the Court mitigated to a large extent the effects of the restrictions imposed by the pandemic, while working to ensure the fairness, efficiency and openness of its proceedings.

Arguably, the long-term effects of the pandemic on the work of the Court, which has a busy but still limited docket, will not be as pervasive as for other courts that have huge caseloads. The delay in pleadings and hearings will inevitably increase the length of the proceedings in certain cases, but when the pandemic subsides, the Court will not face any significant backlog. While the Court has so far been accommodating of Covid-related requests for postponements by the parties, it is likely that it will show less tolerance towards such requests in the future.

The pandemic offers the Court, alongside other judicial institutions around the world, an opportunity for reform. A key decision that the Court will have to make is whether to retain virtual judicial meetings and hearings when no longer required by government regulations. The majority of our interviewees answered affirmatively, a view with which we agree. ${ }^{126}$ Remote and hybrid participation should be retained as an option, subject to the consent of the parties, in cases where a judge or advocate cannot appear in person, or for urgent hearings on the indication of provisional measures. ${ }^{127}$ The main advantages of remote or hybrid hearings are: facilitating the scheduling of the hearing; processing the case more quickly; economies of scale for the parties, which

\footnotetext{
${ }^{121}$ Interview with advocate 1 . See also interviews with advocates 4,8 .

${ }^{122}$ Interview with advocate 7 .

${ }^{123}$ Interview with advocate 5 .

${ }^{124}$ Ibid.

${ }^{125}$ See Susskind, supra note 53.

${ }^{126}$ Interviews with advocates $1,2,4,6,7,8$, 9; interview with Registry official; interview with state representative.

${ }^{127}$ Interview with advocate 9.
} 
may be especially significant for developing countries; and environmental benefits of less longhaul air travel.

Certain features of the Court's oral proceedings (such as their publicity and the fact that they are typically dedicated to scripted oral submissions rather than witness examination or exchanges between counsel and the Bench) make them better suited to be conducted remotely than proceedings before domestic or other international courts. ${ }^{128}$ However, our research also indicates that at least three features of inter-state dispute settlement render physical presence important: the function of the symbolism of adjudication, which is stronger when parties are present in the Great Hall of Justice; the diplomatic component of settling disputes between states, which benefits from inperson gatherings and opportunities for corridor conversations; and the importance of effective advocacy for guiding the Bench through vast amounts of case materials. Physical presence also matters for interpreters, who play a crucial role in the smooth conduct of oral pleadings. These are important aspects that deserve consideration as the Court plans its next steps.

Some scholars are advocating for courts in general to make use of technology to deliver online services that are more accessible, affordable and understandable than traditional in-person services. ${ }^{129}$ This includes using virtual hearings as a matter of course, rather than as an emergency response to an emergency situation. ${ }^{130}$ At the same time, the current emergency creates a need for states to carefully consider their options 'for the efficient, timely and cost-effective resolution of their disputes'. ${ }^{131}$ This may lead to an increasing demand for dispute resolution methods other than judicial settlement before the ICJ (e.g., negotiation, mediation or arbitration). It is noteworthy, and perhaps unsurprising, that no new cases were brought before the Court in 2020, and only one in 2021 at the time of writing. ${ }^{132}$ In our view, the fact that the Court is an institution embedded in the UN system and providing stability and foreseeability militates in favour of states continuing to choose the ICJ for the settlement of inter-state disputes. But it must remain competitive. The Court has an opportunity to move with the times and attract more cases in the future. Remote or hybrid hearings could help lower the cultural barriers for participation, especially for states having limited experience with ICJ litigation. The ritual and mores of the International Bar can make it intimidating to appear before the ICJ Bench, and remote or hybrid participation could make the Court more accessible. ${ }^{133}$

If the practice of remote and hybrid hearings continues at the ICJ, there are a number of adjustments we recommend that the Court consider. First, equality between the parties must be protected. As Judge Greenwood observed in an advisory opinion context, inequality between the parties 'is incompatible with modern notions of justice and due process'. ${ }^{134}$ The Court should take all necessary steps to avoid and alleviate any inequalities in the positions of the parties and facilitate their effective participation in remote and hybrid proceedings. ${ }^{135}$ To be on an equal footing,

\footnotetext{
${ }^{128}$ There is limited evidence coming from surveys at domestic level that remote hearings are most suitable for cases on appeal or without witnesses. Sanders, supra note 6. Susskind argues that a growing consensus is emerging that cases involving serious crime, family disputes that involve the custody of children or domestic abuse should be heard in person if possible. Interim, procedural, and interlocutory hearings; routine family work; small money claims; minor criminal offences; commercial disputes; administrative tribunals and civil appeals, amongst others, can be held remotely. See Susskind, supra note 53 . The suitability for a matter to be heard remotely may need to be determined on a case-by-case basis, taking into accounts the rights of those concerned. International Commission of Jurists, supra note 60.

${ }^{129} \mathrm{R}$. Susskind, Online Courts and the Future of Justice (2019).

${ }^{130}$ See Susskind, supra note 53.

${ }^{131}$ K. Fan, 'The Impact of COVID-19 on the Administration of Justice', Kluwer Arbitration Blog, 10 July 2020, available at www. arbitrationblog.kluwerarbitration.com/2020/07/10/the-impact-of-covid-19-on-the-administration-of-justice/.

${ }^{132}$ Dispute between Gabon and Equatorial Guinea brought before the Court, Press Release No. 2021/10, 5 March 2021.

${ }^{133}$ Interview with state representative.

${ }^{134}$ Judgment No. 2867 of the Administrative Tribunal of the International Labour Organization upon a Complaint Filed against the International Fund for Agricultural Development, Advisory Opinion of 1 February 2012, [2012] ICJ Rep. 10 (Judge Greenwood), para. 4.

${ }^{135}$ See mutatis mutandis ibid., para. 45.
} 
the parties need clear and timely information from the Court on the applicable sanitary regulations upon arrival in the Netherlands and on the composition and form of participation of each party's delegation. The Court should also be mindful of the parties' sensitivities towards judges ad hoc and their ability to contribute the Court's decision-making in conditions of complete equality with the other judges. If one party's participation is hindered by poor technical support, then arrangements should be made for that state to participate from its embassy in The Hague or a UN facility in the relevant capital city. The Secretary-General's Trust Fund to Assist States in the Settlement of Disputes through the International Court of Justice may also be a source of financial support to ensure equal participation.

Second, our research shows how important it is for advocates to have a good view of the Bench during their pleadings. We recommend the Court consider making some adjustments to the courtroom set-up to facilitate a clear view of all Judges. We also recommend that witness examination in hybrid hearings should be adjusted to allow better interaction between the advocate and the witness. There should be a facility for the parties to message the Registrar or the relevant IT expert to resolve legal and technical questions even if their counsel does not have the floor.

Third, this is an opportunity for improved procedures for remote witness examination, electronic filing of judges' folders (and the expanded use of electronic filing for pleadings), and effective cybersecurity standards. ${ }^{136}$ As there are many judicial and arbitral institutions facing similar challenges, it would make good sense for the Court to engage in discussions on lessons learned and best practices with, for example, the Permanent Court of Arbitration.

Fourth, there is a widespread consensus that the Court should retain - and develop further the practice of virtual case-management meetings between the President and representatives of the parties, even when no longer required by government regulations. ${ }^{137}$ More frequent advance meetings, more easily arranged online rather than in person, will help ensure convenient scheduling and secure and smooth document management. Such meetings will also provide great comfort and transparency to those states appearing before the Court for the first time.

The legacy of the pandemic for the ICJ will be more than the Perspex barriers dividing the judges and the empty chairs in the Great Hall of Justice. The legacy can also be significantly improved procedures at the Court, both in terms of how and when it engages with the parties and with regard to the practicalities of case management, always ensuring equality between the parties. Even when the Court's activities can resume as normal, we hope that the Court will harness the wider benefits that have been identified during this period.

\footnotetext{
${ }^{136}$ E.g., those in the Protocol on Virtual Hearings in Africa by the Africa Arbitration Academy (April 2020).

${ }^{137}$ Interviews with advocates $1,4,5,7,9$; interview with state representative. A similar recommendation was made by the ILA Final Report, at 6. Contra: interview with advocate 3.
}

Cite this article: Pinzauti G and Webb P (2021). Litigation before the International Court of Justice during the pandemic. Leiden Journal of International Law 34, 787-800. https://doi.org/10.1017/S0922156521000406 